\title{
Improved Resistance Against Botrytis cinerea by Grapevine-Associated Bacteria that Induce a Prime Oxidative Burst and Phytoalexin Production
}

\author{
Bas Verhagen, Patricia Trotel-Aziz, Philippe Jeandet, Fabienne Baillieul, and Aziz Aziz
}

First, second, and fifth authors: Plantes Pesticides \& développement Durable, third author: Enologie \& Chimie Appliquée, and fourth author: Stress Defenses \& reproduction des Plantes, URVVC-Stress \& Environment EA 2069, University of Reims, F-51687 Reims cedex 2, France.

Accepted for publication 10 March 2011.

\begin{abstract}
Verhagen, B., Trotel-Aziz, P., Jeandet, P., Baillieul, F., and Aziz, A. 2011. Improved resistance against Botrytis cinerea by grapevine-associated bacteria that induce a prime oxidative burst and phytoalexin production. Phytopathology 101:768-777.

Bacteria such as Pantoea agglomerans (Pa-AF2), Bacillus subtilis (Bs271), Acinetobacter lwoffii (Al-113), and Pseudomonas fluorescens (PfCT2), originating from the vineyard, can induce defense responses and enhance resistance of grapevine against the fungal pathogen Botrytis cinerea. The perception of these bacteria by plant cells or tissues in relation to their activities remains unknown. In this study, we examined the relationships between the activity of each bacterium to induce or prime some defense responses, and its effectiveness to induce resistance in grapevine against $B$. cinerea. We showed that all selected bacteria are capable of inducing early oxidative burst and phytoalexin (trans-

phytoalexin production after $B$. cinerea challenge. These two bacteria were also the most effective in inducing local and systemic resistance. A similar level of induced resistance was observed with live Pa-AF2 which also induced but not primed a greater accumulation of trans-resveratrol. However, Bs-271, which was less effective in inducing resistance, induced a lower trans-resveratrol synthesis, without priming activity. Treatment of grapevine cells with growing medium or crude extract of the bacteria quickly and strongly enhanced oxidative burst compared with the live bacteria. However, both treatments resulted in comparable amounts of phytoalexins and induced local and systemic resistance to B. cinerea as compared with those induced by living bacteria, with extracts from PfCT2 and Al-113 being the most effective. Together, these results indicate that induced resistance can be improved by treatment with bacteria or derived compounds which induced or primed plants for enhanced phytoalexin accumulation.
\end{abstract} resveratrol and trans- $\varepsilon$-viniferin) production in grapevine cells and leaves. Pf-CT2 and Al-113 induced higher $\mathrm{H}_{2} \mathrm{O}_{2}$ and trans-resveratrol accumulations, and were able to further prime plants for accelerated
Additional keywords: defense reactions, gray mold, ISR, Vitis vinifera.
Plants have evolved the ability to enhance their basal resistance after perception of specific biotic or abiotic stimuli, such as root colonization by selective rhizobacteria or selected microbialassociated molecular patterns (MAMPs) $(4,21,33,45,51)$. The resistance induced is often expressed systemically in organs that are not yet damaged by the pathogen. This so-called induced systemic resistance (ISR) not only appears to be dependent on direct activation of plant defense mechanisms before pathogen attack but also may result from a sensitization of the tissues to express basal defense mechanisms more rapidly and more strongly after subsequent challenge with particularly necrotrophic pathogens or even insects $(37,44)$. This sensitization of the plant's innate immune system is commonly referred to as "priming" (11). Although the priming and induction of direct defense constitute different mechanisms of protection, both result in a phenotypically similar resistance to pathogens (18). Furthermore, some induced resistance phenomena are based on a combination of both mechanisms.

The capacity to trigger ISR has been shown in many plant species, such as tomato, bean, radish, Arabidopsis, and rice (14,

Corresponding author: A. Aziz; E-mail address: aziz.aziz@univ-reims.fr

* The $e$-Xtra logo stands for "electronic extra" and indicates that Figure 5 appears in color online.

doi:10.1094/PHYTO-09-10-0242

(C) 2011 The American Phytopathological Society
$26,29,36)$. The ability of bacteria to enhance resistance appears to be plant-bacterium specific, because Pseudomonas putida isolate WCS358 induced resistance in Arabidopsis and grapevine but not in radish $(26,46,47,51)$. The induced resistance also appears to be effective against several but not all pathogens $(36,47)$. For example, ISR elicited by $P$. fluorescens WCS417r is not accompanied by a direct activation of pathogenesis-related $(P R)$ genes (36) but leads to priming of predominantly jasmonic acid (JA)and ethylene (ET)-responsive genes $(38,48,50)$.

The establishment of ISR depends on recognition of bacterial elicitors by the plant roots. Over the past decade, a number of bacterial compounds operative in triggering ISR have been identified as cell surface components, such as lipopolysaccharides (LPS), peptidoglycans (PGNs) or flagellin, secreted metabolites, including antibiotics, quorum-sensing molecules, cyclic lipopeptides, volatiles, and iron-regulated metabolites with siderophore activity $(7,19,29,34,51)$. Bacterial LPS and flagellin have been demonstrated to be heat-stable compounds that act as inducers of plant defense responses and may activate basal resistance and reduce disease severity in host plants $(21,31,33)$. In general, most rhizobacteria show redundancy in ISR-triggering compounds, and their effects can be complementary. Moreover, the mechanisms involved in rhizobacteria-mediated ISR tend to vary among bacteria and pathosystems.

Various inducible defense responses have been characterized in grapevine during interaction with pathogenic fungi and elicitors $(3-5,8,9,49)$. Induced defense reactions can be restricted to the tissues close to the site of elicitation or can be expressed 
systemically throughout the tissue or the whole plant. The release of active oxygen species (AOS) such as $\mathrm{H}_{2} \mathrm{O}_{2}$ is one of the early defense responses induced by elicitor molecules that enhance resistance against Botrytis cinerea and Plasmopara viticola (3$5,43,49)$. Similarly, it has been shown that the AOS response is induced in tobacco and grapevine cell suspensions by rhizobacteria or bacterial elicitors that could be linked to the development of ISR in whole plants $(45,51) . \mathrm{H}_{2} \mathrm{O}_{2}$ can diffuse freely across membranes and, therefore, has been implicated in signal transduction and the activation of defense responses (4). This AOS can lead to cell wall protein crosslinking, thereby strengthening the cell wall (24).

Another well-characterized defense response in grapevine is the accumulation of host-synthesized stilbenic phytoalexins, especially trans-resveratrol (3,5,4'-tryhydroxystilbene) and its oligomer, trans- $\varepsilon$-viniferin $(1,5,6,12,13,20,25,35)$. These stilbenic compounds are selectively accumulated in leaves and grape skins in response to fungal infections, UV radiation, MAMPs, or chemicals $(5,6,13,20)$ and were shown to be associated with plant resistance to the pathogens $(1,5,6,12,20,25,51)$.

To date, research aimed toward understanding induced resistance mechanisms has focused mainly on herbaceous plant species such as Arabidopsis thaliana, tobacco, and rice. However, little is known about biologically induced resistance in woody grapevine plants. Nevertheless, a possible control of gray mold disease (B. cinerea) by Burkholderia spp. originally isolated from the rhizosphere of onion plants has been reported and attributed to a systemic spread of the bacterium in plants (10). In recent work, we have observed that pretreatment of grapevine plants with Pseudomonas fluorescens $\mathrm{CHA} 0$ and $P$. aeruginosa 7NSK2 bacteria or their crude extracts induces defense responses and resistance to subsequent infection with $B$. cinerea (51). In other works, we isolated different bacteria from the rhizosphere and phyllosphere of grapevine plants that induced enhanced resistance to $B$. cinerea $(28,40)$. These bacteria have been identified as distinct isolates of Pantoea agglomerans, Acinetobacter lwoffii, Bacillus subtilis, and Pseudomonas fluorescens (41). The mechanisms involved in the perception of these isolates by plant cells and those underlying bacteria-induced resistance remain unknown. In this study, we compared the activity of each bacterium to induce or prime defense responses in grapevine in relation to their effectiveness in triggering resistance against the fungal pathogen Botrytis cinerea. We focused on early and late defense responses in grapevine cells and leaves: specifically, (i) the induction of oxidative burst and (ii) the production of stilbenic phytoalexins, trans-resveratrol, and its dehydrodimer, trans- $\varepsilon$ viniferin. With a view to characterize bacterial components that could be effective in inducing resistance of grapevine, we also examined the effects of growing media and cell extracts of bacteria on both defense responses and their capacity to induce local and systemic resistance in grapevine plantlets against $B$. cinerea.

\section{MATERIALS AND METHODS}

Cultivation of bacteria. The bacteria used in this study were isolated in our lab from grapevine plants and rhizospheric soil of vineyards in Champagne (France). They were identified as Pantoea agglomerans (Pa-AF2), A. lwoffii (Al-113), Bacillus subtilis (Bs-271), and Pseudomonas fluorescens (Pf-CT2) (41). Bacteria were grown in liquid Luria-Bertani (LB) medium (23) for $24 \mathrm{~h}$ at $28^{\circ} \mathrm{C}$ and $120 \mathrm{rpm}$ as described previously (36). Bacteria were collected by centrifugation and resuspended in $10 \mathrm{mM} \mathrm{MgSO} 4$ at defined concentrations. To check the effects of the medium in which bacteria were grown, the medium fraction was collected as a supernatant after centrifugation of each suspension of live bacteria. The remaining pellets containing bacteria were resuspended in $\mathrm{MgSO}_{4}$ and boiled at $95^{\circ} \mathrm{C}$ for 15 min to obtain crude cell extracts from different initial concen- trations of live bacteria. Both bacterial extracts and growing media were tested to be free of bacteria cells by plating them on $\mathrm{LB}$ agar plates. The control consisted of $\mathrm{MgSO}_{4}$ for live bacteria and their corresponding extracts, and fresh LB for growing media. Colonization of the medium of grapevine plantlets by selected bacteria was examined at the end of each resistance bioassay.

Fungal pathogen cultivation and inoculation. Botrytis cinerea strain 630 (obtained from Y. Brygoo, INRA, Versailles, France) was cultured in Erlenmeyer flasks containing potato dextrose agar (Sigma-Aldrich, St. Louis) for 4 weeks at $22^{\circ} \mathrm{C}$. Spores were collected and resuspended in sterile distilled water to a final density of $1 \times 10^{6}$ conidia/ml. The spores were used immediately for inoculation of leaves as described previously $(4,5)$ or stored in a sterile solution containing $20 \%$ glycerol at $-80^{\circ} \mathrm{C}$ until use.

Plant growth conditions and cell cultures. Grapevine plantlets (Vitis vinifera 'Chardonnay 7535') were obtained in vitro by multiplication through microcuttings on modified medium of Murashige and Skoog (30), as described previously (5). Plantlets were grown at $24^{\circ} \mathrm{C}$ with $16 \mathrm{~h}$ of light and $8 \mathrm{~h}$ of darkness at $70 \%$ humidity. Grapevine cells (V. vinifera 'Gamay') were cultivated in the Nitsch and Nitsch medium (32) without hormones on a rotary shaker $(130 \mathrm{rpm})$ at $25^{\circ} \mathrm{C}$ in continuous light. Cells were maintained in the exponential phase and subcultured $24 \mathrm{~h}$ prior to utilization.

Treatment of cell suspensions. Cells were collected during the exponential growth phase and washed by filtration in a suspension buffer containing $175 \mathrm{mM}$ mannitol, $0.5 \mathrm{mM} \mathrm{K}_{2} \mathrm{SO}_{4}, 0.5 \mathrm{mM}$ $\mathrm{CaCl}_{2}$, and $2 \mathrm{mM}$ MES, pH 5.5. Cells were resuspended at $0.1 \mathrm{~g}$ $\mathrm{FW} / \mathrm{ml}$ in suspension buffer and equilibrated for $2 \mathrm{~h}$ on a rotary shaker $\left(130 \mathrm{rpm}, 24^{\circ} \mathrm{C}\right)$. Grapevine cells were then treated with live bacteria, bacterial extracts, or growing media from defined initial concentrations of live bacteria. Control cells were incubated under the same conditions and treated with $\mathrm{MgSO}_{4}$ solution or with fresh LB medium. Grapevine cells were then used for measurements of $\mathrm{H}_{2} \mathrm{O}_{2}$ production, phytoalexin accumulation, and cell death during treatments.

$\mathrm{H}_{2} \mathrm{O}_{2}$ production. The production of $\mathrm{H}_{2} \mathrm{O}_{2}$ by cells was assayed by chemiluminescence using luminol as described by Aziz et al. (5). Cells were treated and chemiluminescence was measured in a 10-s period with a luminometer (Lumat LB 9507; Berthold, Germany). The amount of $\mathrm{H}_{2} \mathrm{O}_{2}$ produced was quantified by using a standard calibration curve, obtained by treating cell suspensions with known amounts and in the range of 0 to $50 \mu \mathrm{M} \mathrm{H}_{2} \mathrm{O}_{2}$.

Cell death. Cell viability was assayed using the vital dye Neutral Red (Sigma-Aldrich). A 2-ml cell suspension $(0.1 \mathrm{~g}$ $\mathrm{FW} / \mathrm{ml}$ ) in $10 \mathrm{mM}$ HEPES, $0.5 \mathrm{mM} \mathrm{CaCl}_{2}, 0.5 \mathrm{mM} \mathrm{K}_{2} \mathrm{SO}_{4}$, and $175 \mathrm{mM}$ mannitol, pH 5.75, was treated with $20 \mu \mathrm{l}$ of $1 \%$ Neutral Red solution and the cells were incubated on a rotary shaker at room temperature. Cells observed under a light microscope that did not accumulate the dye were considered dead and counted after $24 \mathrm{~h}$ of treatment.

Phytoalexin quantification. The isolation and analysis of phytoalexins in cell cultures was performed essentially as described by Aziz et al. (5). Aliquots $(2 \mathrm{ml}$ ) of cells in the culture medium were collected and filtered on GF/A glass fiber filters. Stilbenes from the cells were extracted in $2 \mathrm{ml}$ of $85 \%$ methanol overnight at $4^{\circ} \mathrm{C}$. After centrifugation $(10 \mathrm{~min}, 5,000 \times g)$, supernatants were evaporated under nitrogen and the samples were solubilized in $1 \mathrm{ml}$ of $100 \%$ methanol. All extraction steps were done in subdued light conditions. The extracts were clarified by filtration through a Millex-GN $0.22-\mu$ m filter (Millipore, StQuentin en Yvelines, France) before high-performance liquid chromatography analysis. Samples were loaded onto a Lichrocart C-18 reversed-phase column (250 by $4 \mathrm{~mm}, 5 \mu \mathrm{m})$ (Waters, StQuentin en y, France) equilibrated with a 90:10 (vol/vol) $\mathrm{H}_{2} \mathrm{O}$ / acetonitrile mobile phase. Phytoalexins were eluted with a linear gradient of 10 to $85 \%$ acetonitrile at a flow rate of $1 \mathrm{ml} / \mathrm{min}$. 
Stilbenic phytoalexins, trans-resveratrol, and trans- $\varepsilon$-viniferin were detected with a photodiode array detector coupled to a fluorometer detector $(\lambda \mathrm{ex}=330 \mathrm{~nm}, \lambda \mathrm{em}=374 \mathrm{~nm})$ and quantified on the basis of standard calibration curves. The isolation and analysis of phytoalexins from leaves followed the same procedures as described by Aziz et al. (6).

Protection assays on detached leaves. For each treatment, leaves were excised from 10-week-old in-vitro-grown grapevine plantlets and treated by floating them, adaxial side downward, on standard buffer ( $2 \mathrm{mM}$ MES, pH 5.9, containing $0.5 \mathrm{mM} \mathrm{CaCl} 2$ and $0.5 \mathrm{mM} \mathrm{K}_{2} \mathrm{SO}_{4}$ ), in the presence of live bacteria or their
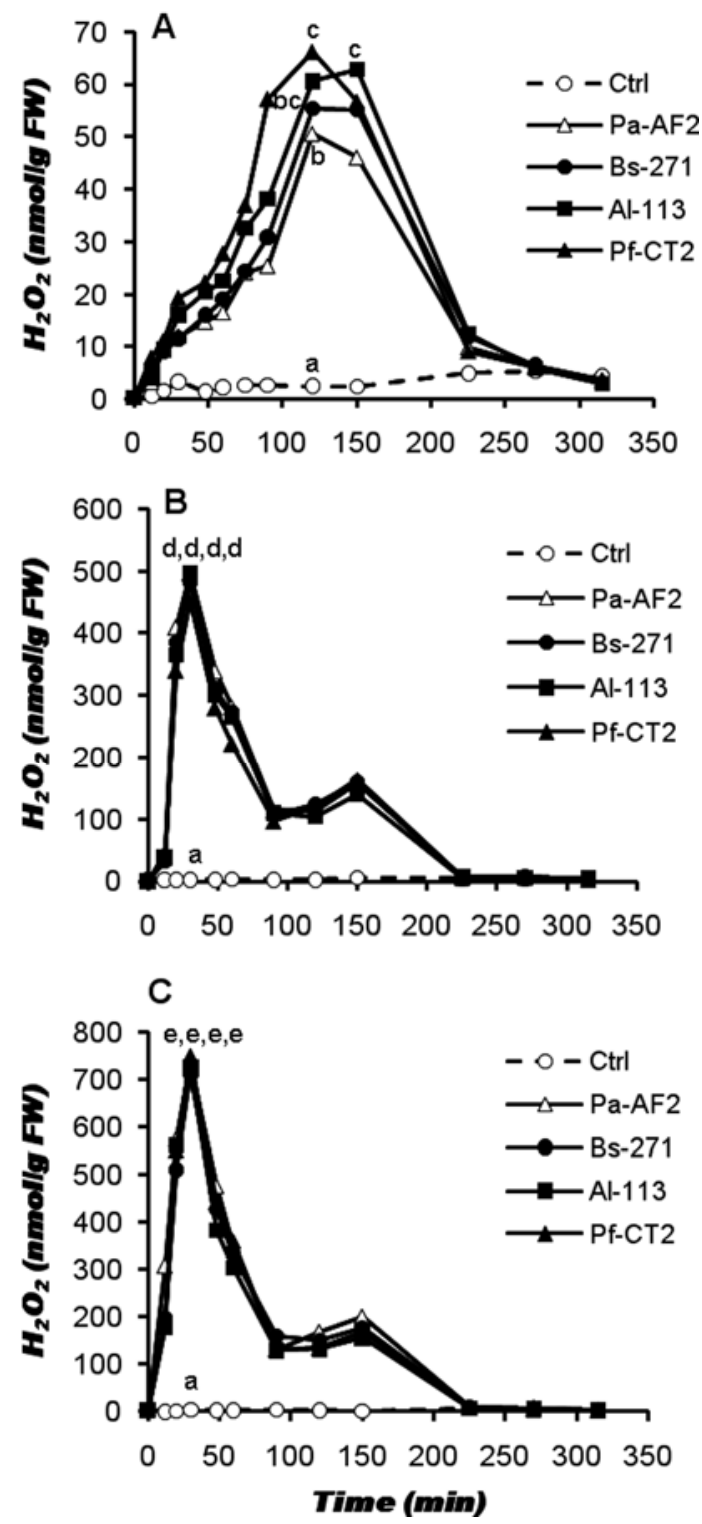

Fig. 1. Active oxygen species (AOS) production by grapevine cell suspensions after treatment with grapevine-associated bacteria, their growing media, and crude extracts. $\mathbf{A}, \mathrm{H}_{2} \mathrm{O}_{2}$ production in grapevine cell suspensions treated with living Pantoea agglomerans (Pa-AF2), Bacillus subtilis (Bs-271), Acinetobacter lwoffii (Al-113), and Pseudomonas fluorescens (Pf-CT2) at 10 $\mathrm{CFU} / \mathrm{ml}$, or in untreated cell suspensions $(\mathrm{Ctrl}) . \mathbf{B}, \mathrm{H}_{2} \mathrm{O}_{2}$ production in grapevine cell suspensions treated with growing media of Pa-AF2, Bs-271, Al-113, and PfCT2 at an initial concentration of live bacteria of $10^{7} \mathrm{CFU} / \mathrm{ml}$, or in LuriaBertani medium-treated cell suspensions (Ctrl). $\mathbf{C}, \mathrm{H}_{2} \mathrm{O}_{2}$ production in grapevine cell suspensions treated with crude cell extracts of Pa-AF2, Bs-271, Al-113, and Pf-CT2 at an initial concentration of live bacteria of $10^{7} \mathrm{CFU} / \mathrm{ml}$, or in $\mathrm{MgSO}_{4}$-treated cell suspensions (Ctrl). Values represent the average of six replicates of one representative experiment out of three. Different letters indicate statistically significant differences between treatments (Tukey's multiple range test; $P<0.05)$. corresponding crude extracts or growing media, with concentrations equivalent to those of live bacteria. After $48 \mathrm{~h}$, leaves were rinsed with distilled water and placed on wet absorbing paper in glass petri dishes. One needle-prick wound was applied to the abaxial side of each leaf, and the fresh wounds were covered with 7.5- $\mu$ l drops of a conidial suspension of $B$. cinerea at $1 \times 10^{6}$ conidia/ml. Quantification of disease development was measured as the average diameter of lesions formed at 5 days postinoculation (DPI), and the average disease in the control (treated with $\mathrm{MgSO}_{4}$ ) was used to calculate the percentage of disease reduction.

ISR. Four-week-old grapevine plantlets were uprooted and treated by dipping the root system in a $20-\mathrm{ml}$ suspension of live bacteria $\left(10^{7} \mathrm{CFU} / \mathrm{ml}\right)$, growing medium, or bacterial extract, with an initial concentration of live bacteria of $10^{7} \mathrm{CFU} / \mathrm{ml}$, for $15 \mathrm{~s}$ before transplanting into a new medium of Murashige and Skoog (30). After 15 or 28 days, 50 to 60 fully expanded leaves were detached from treated and control plantlets and challenge inoculated with $B$. cinerea as described above. The average lesion size was determined after 5 days, and the percent disease reduction was calculated by comparing the treatments with the average lesion size in the challenged control.

Statistical analysis. All experiments were done at least five times per treatment and statistical analyses were performed by two-way analysis of variance and Tukey's multiple comparison test, using SigmaStat 3.5 Systat Software (GmbH, Germany). Differences between mean values were considered to be significant at $P<0.05$.

\section{RESULTS}

Generation of AOS. The oxidative burst is among the early defense responses that could be involved in induced resistance. Grapevine cell suspensions treated with selected bacteria produced a single and transient burst of AOS (Fig. 1A). The amount of $\mathrm{H}_{2} \mathrm{O}_{2}$ increased steadily with the same time kinetics for all isolates until $120 \mathrm{~min}$, when a maximum $\mathrm{H}_{2} \mathrm{O}_{2}$ was reached at $\approx 65 \mathrm{nmol} / \mathrm{g}$ of cells in response to Pf-CT2 and Al-113 and $50 \mathrm{nmol} / \mathrm{g}$ of cells with Bs-271 and Pa-AF2. After this maximum, the amount declined until it reached background levels. The doseresponse curves show that no oxidative burst occurred with a concentration of $10^{5} \mathrm{CFU} / \mathrm{g}$ of grapevine cells, and a threshold at $10^{6} \mathrm{CFU} / \mathrm{g}$ grapevine cells was needed for the induction of a burst of $\mathrm{H}_{2} \mathrm{O}_{2}$ (data not shown).

Addition of the growing medium (in which bacteria were grown) to grapevine cell suspensions also triggered a strong oxidative burst within a few minutes of treatment (Fig. 1B). The maximum amount of $\mathrm{H}_{2} \mathrm{O}_{2}$ was produced at $30 \mathrm{~min}$ and was significantly higher $\left(\mathrm{H}_{2} \mathrm{O}_{2}\right.$ at $500 \mathrm{nmol} / \mathrm{g}$ cells $)$ when compared with live bacteria. It later returned to the basal level after $200 \mathrm{~min}$ and no further increase occurred until the end of experiments.

The bacterial crude extracts also provoked an almost immediate and strong burst of AOS with time kinetics similar to that induced by the growing media (Fig. 1C). The amount of $\mathrm{H}_{2} \mathrm{O}_{2}$ reached a maximum after $30 \mathrm{~min}$ but was significantly higher than that induced by the growing media (Fig. 1B). The maximum amount of $\mathrm{H}_{2} \mathrm{O}_{2}$ produced by grapevine cells was quite similar with the extracts of all bacteria $\left(\mathrm{H}_{2} \mathrm{O}_{2}\right.$ at $\approx 700$ to $740 \mathrm{nmol} / \mathrm{g}$ of cells $)$. This was 12-folds higher when compared with live bacteria. A minimum of initial concentration of bacteria of $10^{5} \mathrm{CFU} / \mathrm{g}$ of cells was required to cause a significant increase in AOS, and the response leveled off above $10^{6} \mathrm{CFU} / \mathrm{g}$ cells (data not shown).

Cell death. The treatment with live bacteria led, in most cases, to a significant cell death during the time course experiments. After $24 \mathrm{~h}, \approx 88 \%$ of cells treated with $\mathrm{Pa}-\mathrm{AF} 2$ were viable, whereas up to 20 and $25 \%$ cells treated with live Al-113 and PfCT2, respectively, were dead (data not shown). In the presence of Bs-271, the percentage of dead cells did not exceed $7 \%$. In 
contrast, none of the growing media or cell extracts of bacteria induced death of grapevine cells. After $24 \mathrm{~h}$, the percentage of dead cells amounted to $6 \%$, comparable with the controls.

Phytoalexin production in grapevine cells. Grapevine phytoalexins belong to the chemical group of stilbenes and these are known to contribute to the protection of plants against various pathogens. To investigate the effect of bacteria and their respective growing media as well as their crude extracts on the defense response of the plant, we analyzed the main stilbenes, transresveratrol and trans- $\varepsilon$-viniferin, in grapevine cells during $48 \mathrm{~h}$ of treatment. Inoculation of grapevine cell cultures with live bacteria induced a transient accumulation of trans-resveratrol (Fig. 2A) and trans- $\varepsilon$-viniferin (Fig. 2B). Maximum accumulation of transresveratrol and trans- $\varepsilon$-viniferin occurred at 16 and $24 \mathrm{~h}$ posttreatment. Elicitation by live Pf-CT2 and Al-113 had the strongest and significant effect on the induction of trans-resveratrol and trans- $\varepsilon$-viniferin synthesis, especially after $16 \mathrm{~h}$ of treatment. PaAF2 induced intermediate phytoalexin accumulation. The amount of trans-resveratrol produced was generally lower with Bs-271 treatment (Fig. 2A), whereas this isolate induced a high accumulation of trans- $\varepsilon$-viniferin (Fig. 2B). Considering both phytoalexins, Pf-CT2 and Al-113 induced the highest accumulations.

Treatment of grapevine cell cultures with the growing media of bacteria also resulted in the accumulation of trans-resveratrol and
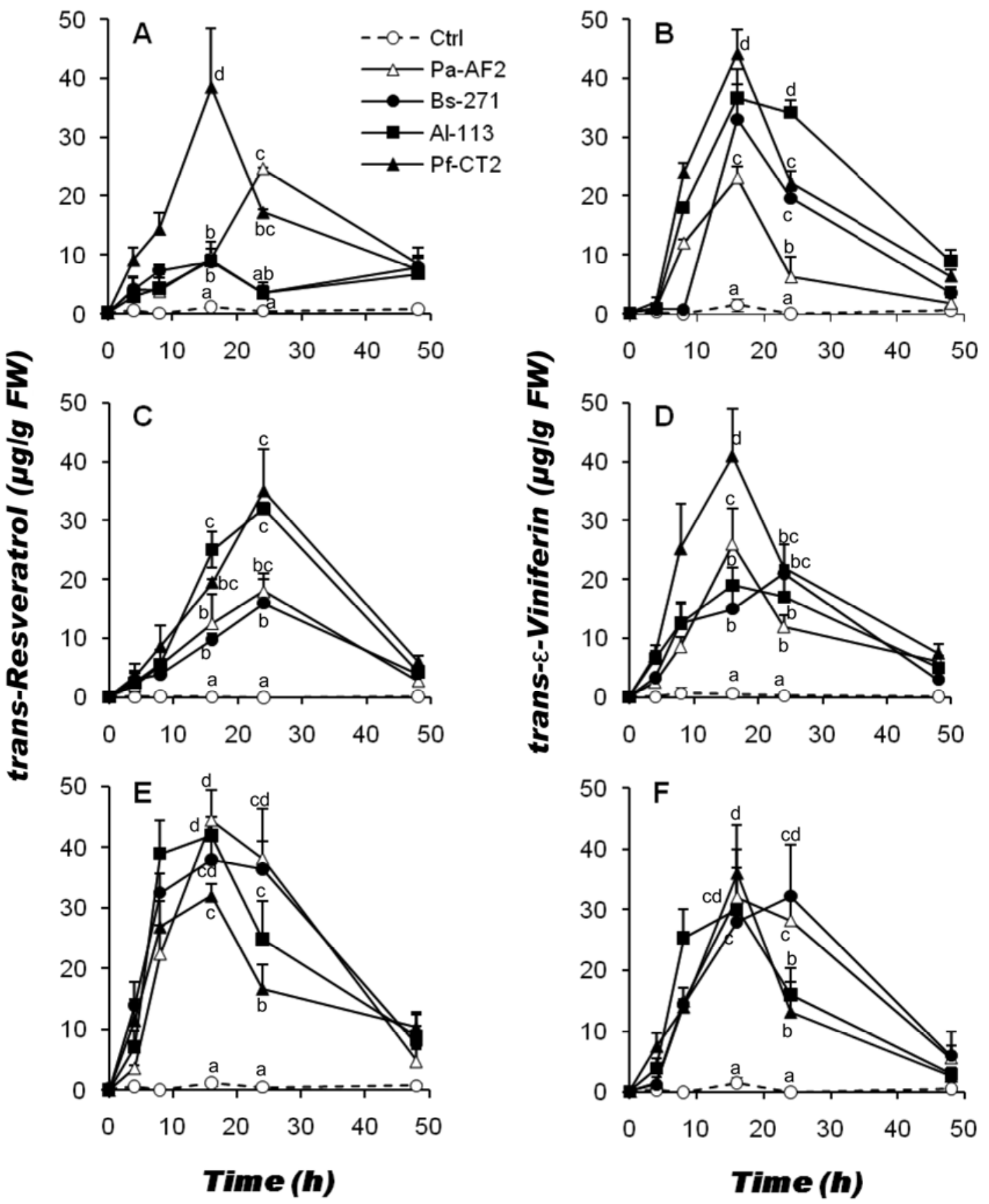

Time (h)

Fig. 2. Production of phytoalexins by grapevine cell suspensions after treatment with living grapevine-associated bacteria, their growing media, and crude extracts. A, trans-Resveratrol and B, trans-e-viniferin production in grapevine cells treated with living Pantoea agglomerans (Pa-AF2), Bacillus subtilis (Bs-271), Acinetobacter lwoffii (Al-113), and Pseudomonas fluorescens (Pf-CT2) at $10^{7} \mathrm{CFU} / \mathrm{ml}$, or in untreated cell suspensions (Ctrl). C, trans-Resveratrol and D, trans- $\varepsilon_{-}^{-}$ viniferin production in grapevine cells treated with growing media of Pa-AF2, Bs-271, Al-113, and Pf-CT2 at an initial concentration of live bacteria of $10^{7} \mathrm{CFU} / \mathrm{ml}$, or in Luria-Bertani-treated cell suspensions (Ctrl). E, trans-Resveratrol and $\mathbf{F}$, trans- $\varepsilon$-viniferin production in grapevine cells treated with crude cell extracts of Pa-AF2, Bs-271, Al-113, and Pf-CT2 at an initial concentration of live bacteria of $10^{7} \mathrm{CFU} / \mathrm{ml}$, or in $\mathrm{MgSO}_{4}$-treated cell suspensions $(\mathrm{Ctrl})$. Values represent the average of six replicates \pm standard deviation. Different letters indicate statistically significant differences between treatments (Tukey's multiple range test; $P<0.05)$. 
trans- $\varepsilon$-viniferin. Phytoalexin production was transient and peaked in all cases at $24 \mathrm{~h}$ after the treatment (Fig. 2C and D). The maximum amount of trans-resveratrol was obtained with the growing medium of Pf-CT2 and Al-113 (Fig. 2C), which was significantly higher (twofold) than that obtained with the growing medium of $\mathrm{Pa}-\mathrm{AF} 2$ and Bs-271. The Pf-CT2 growing medium also induced a strong trans- $\varepsilon$-viniferin accumulation in grapevine cells (Fig. 2D). An intermediate production of trans- $\varepsilon$-viniferin was observed with $\mathrm{Pa}-\mathrm{AF} 2$ growing medium, whereas the growing media of the other two species had lower and similar effects on trans- $\varepsilon$ viniferin accumulation.

Crude extracts from all bacteria were also able to induce a rapid and transient accumulation of the phytoalexins trans-resveratrol and trans- $\varepsilon$-viniferin in grapevine cells (Fig. $2 \mathrm{E}$ and $2 \mathrm{~F}$ ). The maximum amounts of phytoalexins were obtained at $\approx 16 \mathrm{~h}$ after treatment with most of the bacterial extracts. Thereafter, transresveratrol and trans- $\varepsilon$-viniferin accumulation declined progressively. The accumulation of trans-resveratrol appeared to be faster and slightly higher with bacterial extracts (Fig. 2E) when compared with live bacteria (Fig. 2A). Amounts of trans-resveratrol produced were significantly greater with $\mathrm{Pa}-\mathrm{AF} 2$ and $\mathrm{Al}-113$ extracts. Among the different bacterial extracts, there was a slight difference in the amounts of trans- $\varepsilon$-viniferin accumulated (Fig. $2 \mathrm{~F})$. The highest and significant response was observed with extract from Pf-CT2 at $16 \mathrm{~h}$, while trans- $\varepsilon$-viniferin was significantly produced later (after $24 \mathrm{~h}$ of treatment) with extracts from Pa-AF2 and Bs-271.

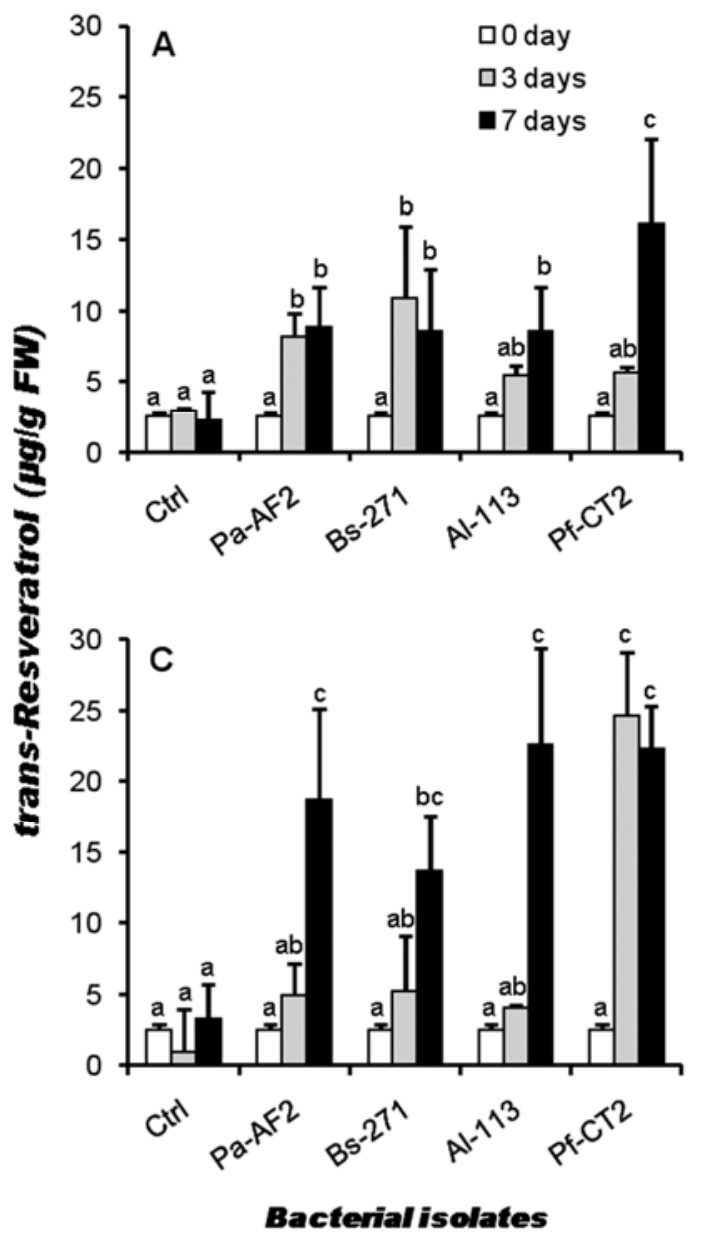

Phytoalexin production in grape leaves. In order to investigate whether the induced phytoalexin accumulation in the cells correlates with that expressed in planta, detached leaves were first treated with selected bacteria or with their corresponding extracts and phytoalexins were analyzed at 0,3 , and 7 days of treatment. None of the treatments led to visible symptoms. In all cases, treatment of grape leaves with live bacteria led to a low induction of trans-resveratrol and trans- $\varepsilon$-viniferin accumulation after 3 days (Fig. 3A and B). The amount of each phytoalexin did not exceed $10 \mu \mathrm{g} / \mathrm{g}$ fresh weight. After 7 days, the level of trans-resveratrol increased but remained comparable in the leaves treated with live Pa-AF2, Bs-271, and Al-113, whereas it was substantially higher with Pf-CT2 treatment (Fig. 3A). After 3 days of treatment, a significant accumulation of the trans- $\varepsilon$-viniferin level was observed only with Pa-AF2 and Pf-CT2 (Fig. 3B). After 7 days of treatment with $\mathrm{Pa}-\mathrm{AF} 2$, the amount of trans- $\varepsilon$-viniferin reached a value of $\approx 10 \mu \mathrm{g} / \mathrm{g}$ but it clearly increased with Bs-271, $\mathrm{Al}-113$, and Pf-CT2 treatments. Considering total phytoalexins, treatment with Pf-CT2 bacterium resulted in the highest accumulation.

Crude extracts from selected bacteria also induced transresveratrol (Fig. 3C) and trans- $\varepsilon$-viniferin (Fig. 3D) accumulation in detached grape leaves when compared with the control. After 3 days of treatment, an increase in trans-resveratrol accumulation was seen only in response to extract of Pf-CT2. Extracts from the other bacteria led to slight increase in trans-resveratrol and trans$\varepsilon$-viniferin. However, significant increases of both phytoalexins

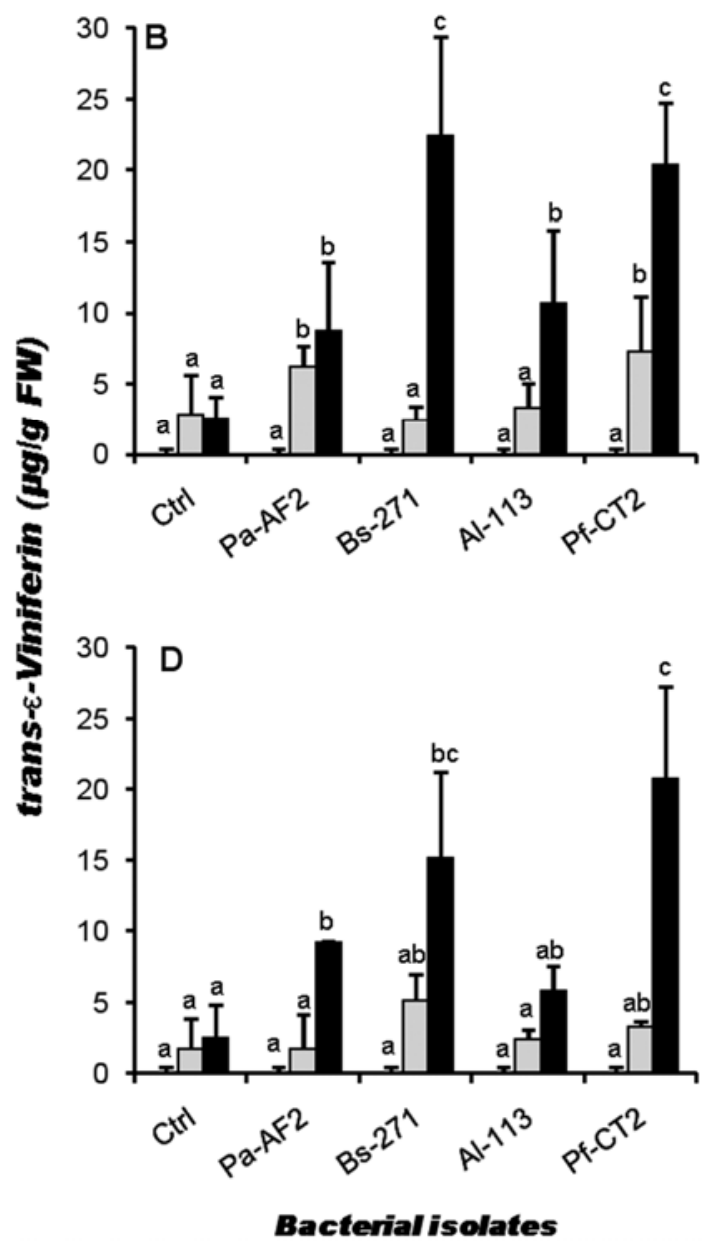

Fig. 3. Production of phytoalexins by grapevine leaves after treatment with living grapevine-associated bacteria and their crude extracts. A, trans-Resveratrol and B, trans- $\varepsilon$-viniferin production in grapevine leaves treated with living Pantoea agglomerans (Pa-AF2), Bacillus subtilis (Bs-271), Acinetobacter lwoffii (Al-113), and Pseudomonas fluorescens (Pf-CT2) at $10^{7} \mathrm{CFU} / \mathrm{ml}$, or in untreated leaves (Ctrl). C, trans-Resveratrol and $\mathbf{D}$, trans- $\varepsilon$-viniferin production in grapevine leaves treated with crude cell extracts of Pa-AF2, Bs-271, Al-113, and Pf-CT2 at an initial concentration of live bacteria of $10^{7} \mathrm{CFU} / \mathrm{ml}$, or in $\mathrm{MgSO}{ }_{4}-$ treated leaves $(\mathrm{Ctrl})$. Values represent the average of three replicates \pm standard deviation of one representative experiment out of three. Different letters indicate statistically significant differences between treatments (Tukey's multiple range test; $P<0.05$ ). 
were observed at 7 days posttreatment with all bacterial extracts. Lower trans-resveratrol accumulation was seen with Bs-271, whereas Pf-CT2 induced the highest phytoalexin biosynthesis.

Induced local and systemic resistance. Local resistance was assayed on detached leaves which were preincubated for $48 \mathrm{~h}$ by floating them on suspensions of live bacteria, growing media, or bacterial extracts and afterwards washed and challenge inoculated with $B$. cinerea. Within 5 DPI, control leaves developed large necrotic lesions (diameter $>16 \mathrm{~mm}$ ). The average lesion diameter was significantly reduced with all treatments when compared with the control (Fig. 4). This reduction was comparable in the leaves treated with live bacteria and their corresponding extracts and varied between 35 and $70 \%$ depending on the bacterium used. Live Pa-AF2, Al-113, and Pf-CT2 bacteria were more effective than Bs-271 (Fig. 4A). Similarly, bacterial extracts of Pa-AF2 and Pf-CT2 were nearly as effective as the live bacteria (Fig. 4C). However, with the growing medium of $\mathrm{Pa}-\mathrm{AF} 2$, disease reduction was $<20 \%$ (Fig. 4B). Whereas the growing media of Bs-271 and Al-113 reduced disease symptoms by 35 to $40 \%$, the growing medium of Pf-CT2 was the most effective and conferred a reduction of disease reaching $60 \%$ relative to the control treated with LB medium.

In order to exclude any direct effects of the bacteria on $B$. cinerea and to investigate whether systemic resistance was induced, roots of grapevine plantlets were treated with living bacteria, growing media, or bacterial extracts, and leaves were detached 2 to 4 weeks later and challenged with $B$. cinerea. Root treatment with live bacteria inhibited disease development in the leaves caused by $B$. cinerea by $\approx 30$ to $50 \%$ (Fig. 5). Pa-AF2, Al113 , and Pf-CT2 were most active in enhancing disease resistance whereas, with Bacillus subtilis, Bs-271-induced resistance was lower. Both growing media and cell extracts of selected bacteria also significantly enhanced the state of resistance against Botrytis cinerea relative to the control (Fig. 5B and C). With growing media, the induced resistance did not exceed $30 \%$, whereas bacterial extract preparations were nearly as effective as the live bacteria in inducing resistance. The growing medium of Pa-AF2 resulted in only a slight disease reduction (Fig. 5B) but its cell extract elicited expression of systemic resistance comparable with that exhibited by the other bacterial extracts (Fig. 5C). These results demonstrate that all bacteria induce both local and systemic resistance but to a different extent. Compounds naturally released into the medium or heat-extracted from bacterial cells seem to be the determinant in inducing disease resistance.

Priming of phytoalexin production after challenge inoculation. Putative priming effects were investigated by quantifying the stilbenic phytoalexins in the leaves of control plants and those treated with live bacteria or their crude extracts upon challenge with the pathogen $B$. cinerea. In $B$. cinerea-infected control plants, a significant accumulation of trans-resveratrol was observed at 1 and 2 DPI and the amount further increased at 5 days after infection with fungal spores (Fig. 6A). In contrast, nonsignificant accumulation of trans- $\varepsilon$-viniferin was observed at 1 to 2 DPI (Fig. 6B) and it significantly accumulated at 5 DPI. Of interest was the fact that trans-resveratrol accumulated earlier and to higher levels in the B. cinerea-infected leaves of the A. lwoffii Al-113-treated and $P$. fluorescens Pf-CT2-treated plants. Thus, priming of the fungus-induced accumulation of phytoalexins occurred in Al-113- and Pf-CT2-treated plants, as was evident by the enhanced accumulation of both phytoalexins after 5 days of pathogen challenge. However, the phytoalexin accumulations were similar in B. cinerea-infected leaves from Pantoea agglomerans Pa-AF2-treated or Bacillus subtilis Bs-271-treated and control plants, indicating that pretreatment with $\mathrm{Pa}-\mathrm{AF} 2$ or Bs271 does not affect the fungus-induced production of stilbenic phytoalexins.

Primed phytoalexin accumulation was also observed in the bacterial extract-treated plants, in which trans-resveratrol and trans- $\varepsilon$-viniferin accumulation after 5 days was stronger than in controls (data not shown). The priming of both phytoalexins was more than five times higher in plants that had been treated earlier with extracts from Al-113 and Pf-CT2 than in the control. By contrast, no priming of phytoalexin production was observed in the leaves of plants pretreated with extracts of $P$. agglomerans $\mathrm{Pa}-$ AF2 and B. subtilis Bs-271 after challenge with Botrytis cinerea.

\section{DISCUSSION}

ISR is a phenomenon whereby state of enhanced defense capacity of plants against subsequent microbial infection is induced at the whole-plant level in response to various endophytic and rhizospheric bacteria. Compared with the experiments focused mainly on herbaceous plant species such as Arabidopsis

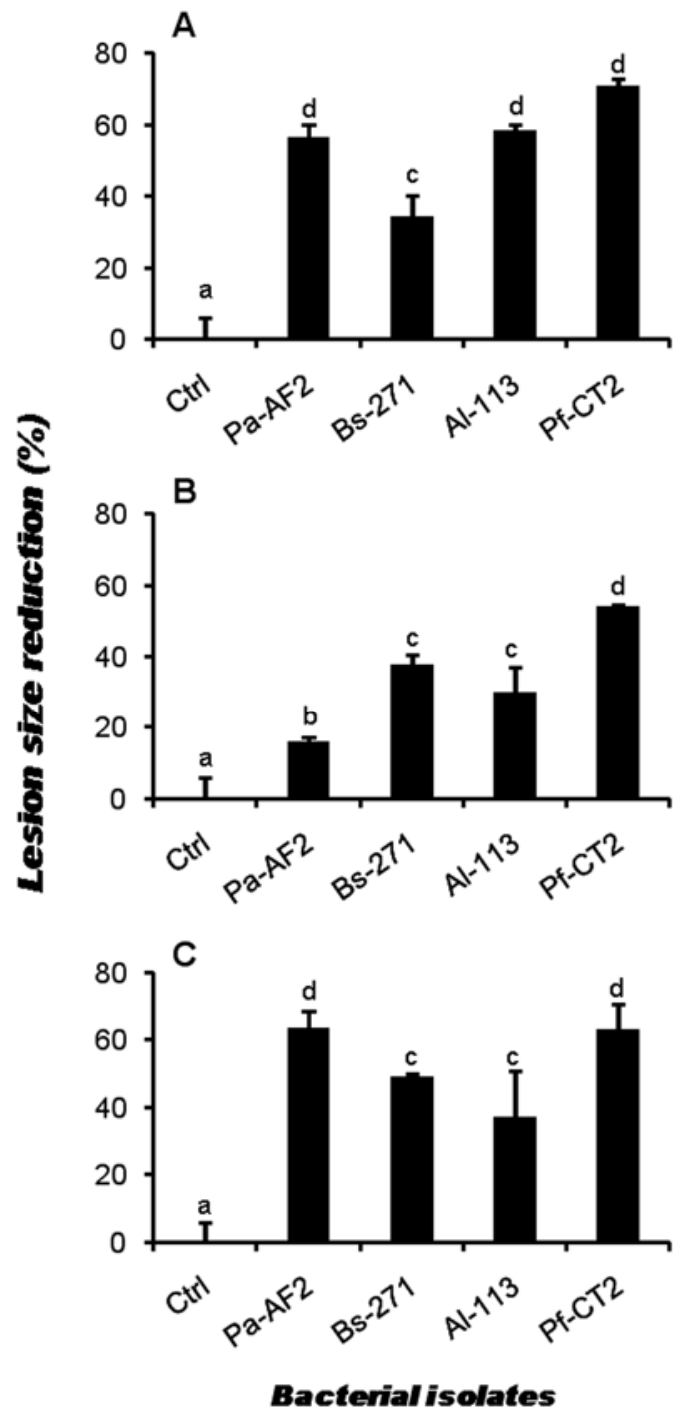

Fig. 4. Protection of detached grapevine leaves against Botrytis cinerea after treatment with live bacteria, their growing media, or crude extracts. A, Reduction of B. cinerea development in detached leaves after treatment with living Pantoea agglomerans (Pa-AF2), Bacillus subtilis (Bs-271), Acinetobacter lwoffii (Al-113), and Pseudomonas fluorescens (Pf-CT2) at 10 $\mathrm{CFU} / \mathrm{ml}$, or in untreated leaves $(\mathrm{Ctrl})$. B, Reduction of Botrytis cinerea development relative to the control in detached leaves after treatment with growing media of Pa-AF2, Bs-271, Al-113, and Pf-CT2 at an initial concentration of live bacteria of $10^{7} \mathrm{CFU} / \mathrm{ml}$, or in Luria-Bertani-treated leaves (Ctrl). C, Reduction of B. cinerea development in detached leaves after treatment with crude cell extracts of Pa-AF2, Bs-271, Al-113, and Pf-CT2 at an initial concentration of live bacteria of $10^{7} \mathrm{CFU} / \mathrm{ml}$, or in $\mathrm{MgSO}_{4}$-treated leaves (Ctrl). Data are mean of at least five experiments, $n \geq 50$. Different letters indicate statistically significant differences between treatments (Tukey's multiple range test; $P<0.05$ ). 

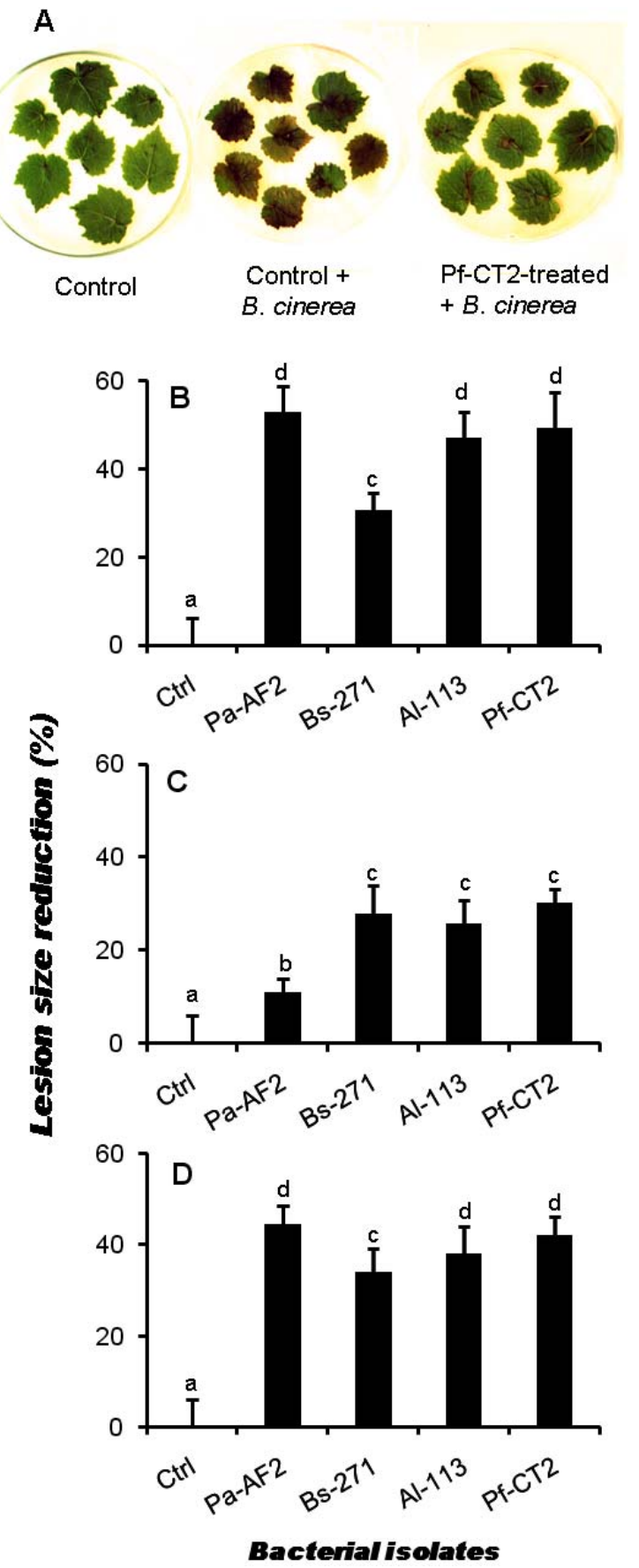

Fig. 5. Induced leaf resistance of grapevine plants against Botrytis cinerea after root treatment with live bacteria, their growing media, or crude extracts. A, Representative photographs depicting macroscopic symptoms on leaves from control or treated plants with Pseudomonas fluorescens Pf-CT2 upon challenge with $B$. cinerea. Images taken at 5 days postinoculation are representative of the results. Similar effects were observed with the other isolates. B, Quantitative assessment of lesion size reduction in the leaves of grapevine plants treated with living Pantoea agglomerans (Pa-AF2), Bacillus subtilis (Bs-271), Acinetobacter lwoffii (Al-113), and Pseudomonas fluorescens (Pf$\mathrm{CT} 2)$ at $10^{7} \mathrm{CFU} / \mathrm{ml}$, or in untreated plants (Ctrl). C, Reduced lesion size in the leaves of grapevine plants treated with growing media of Pa-AF2, Bs-271, Al-113, and Pf-CT2 at an initial concentration of live bacteria of $10^{7} \mathrm{CFU} / \mathrm{ml}$, or in Luria-Bertani-treated plants (Ctrl). D, Reduced lesion size in the leaves of grapevine plants treated with crude cell extracts of Pa-AF2, Bs-271, Al-113, and Pf-CT2 at an initial concentration of live bacteria of $10^{7} \mathrm{CFU} / \mathrm{ml}$, or in $\mathrm{MgSO}_{4}$-treated plants (Ctrl). Data, in percentage of disease reduction compared with the control, are mean of at least five experiments, $n \geq 50$. Different letters indicate statistically significant differences between treatments (Tukey's multiple range test; $P<0.05$ ). thaliana, tobacco, and rice, ISR in economically important grapevine ( $V$. vinifera) is still poorly elucidated. In this work, we have focused on different grapevine-associated bacteria (Pantoea agglomerans Pa-AF2, Acinetobacter lwoffii Al-113, Bacillus subtilis Bs-271, and Pseudomonas fluorescens Pf-CT2) and host defense responses underlying activated ISR in grapevine. We showed that living bacteria or their intracellular or released components can be perceived rapidly by grapevine cells and subsequently trigger some inducible defense-responsive processes that include production of AOS and phytoalexin accumulation. The magnitude of these responses appears to be associated with some induction of cell death. Our data also revealed that treatment of grapevine leaf tissues or roots by selected bacteria renders foliar tissues both locally and systemically more resistant to Botrytis cinerea. This induced resistance seems to be improved by $P$. fluorescens Pf-CT2 and A. lwoffii Al-113 bacteria or derived compounds that induced and primed phytoalexin accumulation upon pathogen challenge.

Rapid production of AOS in plant cells has been recognized as one of the prominent events induced by ISR-triggering bacteria such as Pseudomonas spp. and derived compounds $(45,51)$. Here, we showed that treatment of cell cultures with living bacteria induced a single and transient burst of AOS, characterized by the accumulation of $\mathrm{H}_{2} \mathrm{O}_{2}$. The amount of $\mathrm{H}_{2} \mathrm{O}_{2}$ increased steadily with the same time kinetics for all isolates until $\approx 120 \mathrm{~min}$ but with distinct peak magnitudes. Although this burst was low when compared with that induced by certain MAMPs $(4,5)$, there was
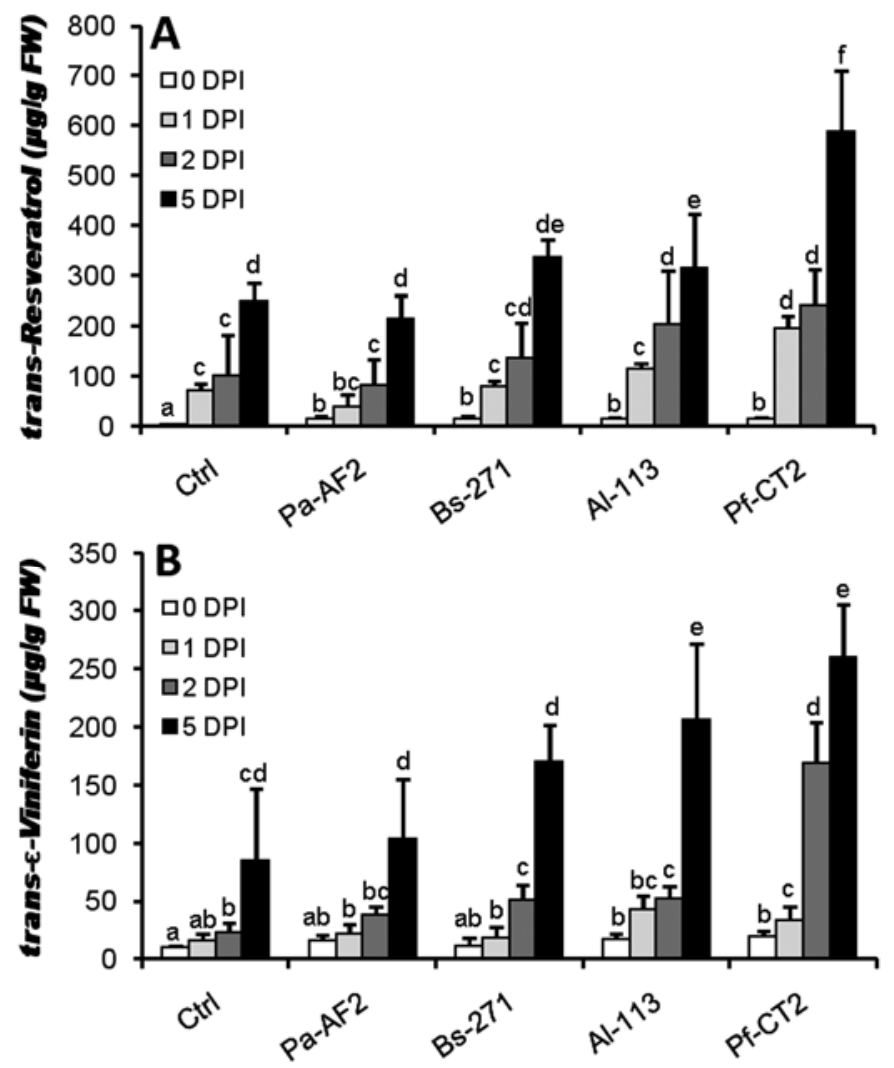

Bacterial isolates

Fig. 6. Priming for phytoalexin production in leaf tissues of grapevine plantlets by living bacteria upon challenge with Botrytis cinerea. Primed A, transresveratrol and $\mathbf{B}$, trans- $\varepsilon$-viniferin production in leaf tissues of grapevine plants treated at the level of roots with living Pantoea agglomerans (Pa-AF2), Bacillus subtilis (Bs-271), Acinetobacter lwoffii (Al-113), and Pseudomonas fluorescens (Pf-CT2) at $10^{7} \mathrm{CFU} / \mathrm{ml}$, or in $\mathrm{MgSO}_{4}$-treated plants (Ctrl) upon challenge with Botrytis cinerea. DPI = days postinoculation. Different letters indicate statistically significant differences between treatments (Tukey's multiple range test; $P<0.05$ ). 
significantly more $\mathrm{H}_{2} \mathrm{O}_{2}$ accumulation in response to $P$. fluorescens and A. lwoffii $\left(\approx 6.5 \mu \mathrm{M} \mathrm{H}_{2} \mathrm{O}_{2}\right)$ than in response to Bacillus subtilis and Pantoea agglomerans $\left(5 \mu \mathrm{M} \mathrm{H}_{2} \mathrm{O}_{2}\right)$. This initially suggested that AOS might play an important role in recognition of bacterial signals that can initiate defense pathways to boost plant immunity. It is possible that the different levels of accumulated $\mathrm{H}_{2} \mathrm{O}_{2}$ could be ascribed to different active compounds or the quantity released by each bacterium in the medium. Indeed, here, we showed that both the medium in which bacteria had grown and the bacterial extract triggered a strong and transient oxidative burst lasting $<30$ min rather than 120 min, as observed with living bacteria (Fig. 1). The magnitude of the reaction indicates that large amounts of active components could be secreted by the bacteria. The short time course of $\mathrm{H}_{2} \mathrm{O}_{2}$ is more in agreement with the timeline observed in grapevine cell cultures after treatment with different MAMPs such as $\beta$-glucans, oligogalacturonides, cellodextrins $(3,4)$, and rhamnolipids $(49)$, in which this response was linked to the expression of defense-related genes and development of leaf resistance against Botrytis cinerea. Similar effects have also been observed in tobacco cell suspensions treated with LPS and flagellin from Pseudomonas spp. (45).

Another important observation is that the induction of an $\mathrm{H}_{2} \mathrm{O}_{2}$ burst requires a minimum population density of $10^{6} \mathrm{CFU} / \mathrm{g}$ for live bacteria and $10^{5} \mathrm{CFU} / \mathrm{g}$ of cells for bacterial extract and growing medium (data not shown). This difference could result from an enhanced concentration of active compounds in bacterial extract and the growing medium, and is in agreement with the observation that a threshold for cell wall extracts corresponding to an initial density of $10^{5} \mathrm{CFU} / \mathrm{g}$ of cells was required for the oxidative burst in cell suspensions of tobacco (45) and grapevine (51). AOS are known to contribute to plant resistance by directly exerting a cytotoxic effect against pathogens, participating in cell wall reinforcement, inducing hypersensitive cell death, or inducing expression of defense genes or the accumulation of antimicrobial compounds $(4,27,39)$. In this study, a significant cell death occurred after treatment with living $P$. agglomerans (12\%), A. Iwoffii (20\%), and Pseudomonas fluorescens (25\%). This seems to be linked to induced long-lasting production of $\mathrm{H}_{2} \mathrm{O}_{2}$ in grapevine cell cultures. These reactions may reflect a differential sensitivity of grapevine cells to selected bacteria. Treatment of grapevine cells with bacterial extracts or growing media quickly and strongly enhanced oxidative burst without inducing any cell death. Typical reactions have also been shown to be induced by various MAMPs triggering the expression of defenserelated genes and resistance against pathogens $(3-5,45,49,51)$.

An important effect that is usually associated with defense responses and direct resistance induction in plants is the production of stilbenic phytoalexins. We have shown that all live bacteria tested induced a slight accumulation of trans-resveratrol and trans- $\varepsilon$-viniferin in the grapevine cells or in the directly treated leaves. The accumulation of both phytoalexins in the leaves was also potentiated by some bacteria after challenge with the fungal pathogen. $P$. fluorescens and A. lwoffii showed the strongest effect, while pretreatment with Pantoea agglomerans and Bacillus subtilis bacteria induced lower responses and did not affect the fungal-induced production of stilbenic phytoalexins. Similar results have been observed with growing media and bacterial extracts. This pattern is redolent of primed plants, in which a defense arsenal had been sensitized rather than fully induced $(11,15)$. Primed plants usually show no enhanced expression of phenotypic defense traits, such as callose deposition and $\mathrm{H}_{2} \mathrm{O}_{2}$ accumulation, but they respond faster or more strongly following a challenge inoculation $(11,15,44)$. Priming of oxidative burst, callose deposition, and expression of the stilbene synthase gene has been reported in grapevine in $\beta$-aminobutyric acid- and sulfated laminarin-induced resistance against Plasmopara viticola $(17,42)$. Phytoalexin synthesis in grapevine is also upregulated by various MAMPs $(4,6,25)$ and live rhizobacteria $(46,51)$ as well as by abiotic stress $(13,20)$, and overexpression of stilbene synthase, the key enzyme responsible for the synthesis of these phytoalexins, confers improved resistance to pathogens (12).

Despite differences in induced or primed defense responses, we showed that treatments of grapevine leaves or intact plants with living bacteria or their crude extracts led to local and systemic resistance against Botrytis cinerea. This is in good agreement with previously published data with these bacteria in vineyards (28). Pseudomonas fluorescens and A. lwoffii induce ISR in grapevine in a manner similar to other known ISR-inducing bacteria originating from the rhizosphere of different plants (51), where bacteria-treated plants displayed a potentiated defense response upon pathogen challenge. The difference between selected bacteria could be attributed to different cellular MAMPs produced. Data also indicate that the magnitude of the oxidative burst is not directly related to the amount of phytoalexins produced. The effects of bacterial extract and growing medium are also in accordance with the production of heat-stable signaling molecules or secreted compounds from Pseudomonas spp. serving as inducers of ISR $(7,45,51)$. The bacterial cell wall is an important source of MAMPs, such as PGNs recognized by Arabidopsis (16), LPS active in dicots and monocots (31), purified rhamnolipids recognized by grapevine (49), and cyclic lipopeptides that stimulate defense responses in tobacco (22). The differential induction of AOS burst and phytoalexin production by living bacteria and its derived components suggests that the two responses are regulated via distinct signaling pathways. This is consistent with the previous results indicating that oxidative burst could be independent on the stilbene synthase gene expression and phytoalexin production $(4,27)$ but is required for other MAMP-induced defense pathways in grapevine (4) and priming in tobacco (2).

In conclusion, these results showed that different bacterial species associated with grapevine are capable of inducing and, in some cases, priming oxidative burst and phytoalexin (transresveratrol and trans- $\varepsilon$-viniferin) production, leading to differential local and systemic resistance to $B$. cinerea. The early increase in production of $\mathrm{H}_{2} \mathrm{O}_{2}$ by grapevine cells was not necessarily linked to the enhanced resistance in plants. Nevertheless, induced resistance by $P$. fluorescens Pf-CT2 and A. lwoffii Al-113 as well as by their derived components appears to be associated with both induction and priming of local and systemic plant defenses. $P$. agglomerans $\mathrm{Pa}-\mathrm{AF} 2$, which is among the most effective in inducing local and systemic resistance, can induce but not prime plants for accelerated phytoalexin accumulation after $B$. cinerea challenge. Bacillus subtilis Bs-271 was less effective in inducing resistance against Botrytis cinerea, and resulted in a lower induction of phytoalexin synthesis. Research work is in progress to further characterize intracellular and released bacterial compounds that could be determinant of ISR, and elucidate the signaling pathways involved in the bacteria-inducing resistance against different diseases.

\section{ACKNOWLEDGMENTS}

We thank Champagne-Ardenne Region and Europol'Agro for financial support of this research and B. Verhagen's post-doc position, and C. Clément and P. Vatsa for their valuable comments and helpful review of the manuscript.

\section{LITERATURE CITED}

1. Adrian, M., Jeandet, P., Veneau, J., Weston, L. A., and Bessis, R. 1997. Biological activity of resveratrol, a stilbenic compound from grapevines, against Botrytis cinerea, the causal agent for gray mold. J. Chem. Ecol. 23:1689-1702.

2. Ahn, P., Lee, S. W., and Suh, S. C. 2007. Rhizobacteria-induced priming in Arabidopsis is dependent on ethylene, jasmonic acid, and NPR1. Mol. Plant-Microbe Interact. 20:759-768. 
3. Aziz, A., Gauthier, A., Bézier, A., Poinssot, B., Joubert, J. M., Pugin, A., Heyraud, A., and Baillieul, F. 2007. Elicitor and resistance-inducing activities of $\beta-1,4$ cellodextrins in grapevine, comparison with $\beta-1,3$ glucans and $\beta-1,4$ oligogalacturonides. J. Exp. Bot. 58:1463-1472.

4. Aziz, A., Heyraud, A., and Lambert, B. 2004. Oligogalacturonide signal transduction, induction of defense-related responses and protection of grapevine against Botrytis cinerea. Planta 218:767-774.

5. Aziz, A., Poinssot, B., Daire, X., Adrian, M., Bezier, A., Lambert, B., Joubert, J. M., and Pugin, A. 2003. Laminarin elicits defense responses in grapevine and induces protection against Botrytis cinerea and Plasmopara viticola. Mol. Plant-Microbe Interact. 16:1118-1128.

6. Aziz, A., Trotel-Aziz, P., Dhuicq, L., Jeandet, P., Couderchet, M., and Vernet, G. 2006. Chitosan oligomers and copper sulfate induce grapevine defense reactions and resistance to gray mold and downy mildew. Phytopathology 96:1188-1194.

7. Bakker, P. A. H. M., Pieterse, C. M. J., and Van Loon, L. C. 2007. Induced systemic resistance by fluorescent Pseudomonas spp. Phytopathology 97:239-243.

8. Bézier, A., Lambert, B., and Baillieul, F. 2002. Study of defense-related gene expression in grapevine leaves and berries infected with Botrytis cinerea. Eur. J. Plant Pathol. 108:111-120.

9. Busam, G., Kassemeyer, H. H., and Matern, U. 1997. Differential expression of chitinase in Vitis vinifera L. responding to systemic acquired resistance activators or fungal challenge. Plant Physiol. 115:1029-1038

10. Compant, S., Reiter, B., Sessitsch, A., Nowak, J., Clement, C., and Ait Barka, E. 2005. Endophytic colonization of Vitis vinifera L. by plant growth-promoting bacterium Burkholderia sp. strain PsJN. Appl. Environ. Microbiol. 71:1685-1693.

11. Conrath, U., Beckers, G. J. M., Flors, V., Garcia-Agustin, P., Jakab, G., Mauch, F., Newman, M. A., Pieterse, C. M. J., Poinssot, B,. Pozo, M. J., Pugin, A. Schafffrath, U., Ton, J., Wendehenne, D., Zimmerli, L., and Mauch-Mani, B. 2006. Priming: getting ready for battle. Mol. PlantMicrobe Interact. 19:1062-1071

12. Coutos-Thevenot, P., Poinssot, B., Bonomelli, A., Yean, H., Breda, C., Buffard, D., Esnault, R., Hain, R., and Boulay, M. 2001. In vitro tolerance to Botrytis cinerea of grapevine 41B rootstock in transgenic plants expressing the stilbene synthase Vst1 gene under the control of a pathogen-inducible PR 10 promoter. J. Exp. Bot. 52:901-910.

13. Delaunois, B., Cordelier, S., Conreux, A., Clément, C., and Jeandet, P. 2009. Molecular engineering of resveratrol in plants. Plant Biotechnol. J. $7: 2-12$

14. De Vleesschauwer, D., Djavaheri, M., Bakker, P. A. H. M., and Höfte, M. 2008. Pseudomonas fluorescens WCS374r-induced resistance in rice against Magnaporthe oryzae is based on pseudobactin-mediated priming for a salicylic acid-repressible multifaceted defense response. Plant Physiol. 148:1996-2012.

15. Goellner, K., and Conrath, U. 2008. Priming: it's all the world to induced disease resistance. Eur. J. Plant Pathol. 121:233-242.

16. Gust, A. A., Biswas, R., Lenz, H. D., Rauhut, T., Ranf, S,. Kemmerling, B,. Götz, F., Glawischnig, E., Lee, J., Felix, G., and Nürnberger, T. 2007. Bacteria-derived peptidoglycans constitute pathogen-associated molecular patterns triggering innate immunity in Arabidopsis. J. Biol. Chem. 282:32338-32348.

17. Hamiduzzaman, M. M., Jakab, G., Barnavon, L., Neuhaus, J. M., and Mauch-Mani, B. 2005. $\beta$-Aminobutyric acid-induced resistance against downy mildew in grapevine acts through the potentiation of callose formation and jasmonic acid signaling. Mol. Plant-Microbe Interact. 18:819-829.

18. Heil, M., and Silva Bueno, J. C. 2007. Within-plant signaling by volatiles leads to induction and priming of an indirect plant defense in nature. Proc. .Natl. Acad. Sci. USA 104:5467-5472.

19. Iavicoli, A., Boutet, E., Buchala, A., and Metraux, J. P. 2003. Induced systemic resistance in Arabidopsis thaliana in response to root inoculation with Pseudomonas fluorescens CHA0. Mol. Plant-Microbe Interact. 16:851-858.

20. Jeandet, P., Douillet-Breuil, A. C., Bessis, R., Debord, S., Sbaghi, M., and Adrian, M. 2002. Phytoalexins from the Vitaceae: biosynthesis, phytoalexin gene expression in transgenic plants, antifungal activity, and metabolism. J. Agric. Food Chem. 50:2731-2741.

21. Jones, J. D. G., and Dangl, J. L. 2006. The plant immune system. Nature 444:323-329.

22. Jourdan, E., Henry, J., Duby, F., Dommes, J., Barthélemy, J. P., Thonart, P., and Ongena, M. 2009. Insights into the defense-related events occurring in plant cells following perception of surfactin-type lipopeptide from Bacillus subtilis. Mol. Plant-Microbe Interact. 22:456-468.

23. King, E. O., Ward, M. K., Raney, D. E. 1954. Two simple media for the demonstration of phycocyanin and fluorescin. J. Lab. Clin. Med. 44:301307.

24. Lamb, C., and Dixon, R. A. 1997. The oxidative burst in plant disease resistance. Annu. Rev. Plant Physiol. Plant Mol. Biol. 48:251-275.
25. Laquitaine, L., Gomes, E., Francois, J., Marchive, C., Pascal, S., Hamdi, S., Atanassova, R., Delrot, S., and Coutos-Thevenot, P. 2006. Molecular basis of ergosterol-induced protection of grape against Botrytis cinerea: induction of type I LTP promoter activity, WRKY, and stilbene synthase gene expression. Mol. Plant-Microbe Interact. 19:1103-1112.

26. Leeman, M., Van Pelt, J. A., Den Ouden, F. M., Heinsbroek, M., Bakker, P. A. H. M., and Schippers, B. 1995. Induction of systemic resistance against Fusarium wilt of radish by lipopolysaccharides of Pseudomonas fluorescens. Phytopathology 85:1021-1027.

27. Levine, A., Tenhaken, R., Dixon, R., and Lamb, C. 1994. $\mathrm{H}_{2} \mathrm{O}_{2}$ from the oxidative burst orchestrates the plant hypersensitive disease resistance response. Cell 79:583-593.

28. Magnin-Robert, M., Trotel-Aziz, P., Quantinet, D., Biagianti, S., and Aziz, A. 2007. Biological control of Botrytis cinerea by selected grapevine-associated bacteria and stimulation of chitinase and $\beta-1,3$ glucanase activities under field conditions. Eur. J. Plant Pathol. 118:43-57.

29. Meziane, H, Van der Sluis, I., Van Loon, L. C., Höfte, M., and Bakker, P. A. H. M. 2005. Determinants of Pseudomonas putida WCS358 involved in inducing systemic resistance in plants. Mol. Plant Pathol. 6:177-185.

30. Murashige, T., and Skoog, F. 1962. A revised medium for rapid growth and bioassays with tobacco cultures. Physiol. Plant. 15:473-496.

31. Newman, M. A., Dow, J. M., Molinaro, A., and Parrilli, M. 2007. Priming, induction and modulation of plant defense responses by bacterial lipopolysaccharides. J. Endotoxin Res. 13:69-84.

32. Nitsch, J. P., and Nitsch, C. 1969. Haploid plants from pollen grains. Science 169:85.

33. Nurnberger, T., Brunner, F., Kemmerling, B., and Piater, L. 2004. Innate immunity in plants and animals: striking similarities and obvious differences. Immunol. Rev. 198:249-266.

34. Ongena, M., Jourdan, E., Adam, A., Paquot, M., Brans, A., Joris, B., Arpigny, J. L., and Thonart, P. 2007. Surfactin and fengycin lipopeptides of Bacillus subtilis as elicitors of induced systemic resistance in plants. Environ. Microb. 9:1084-1090.

35. Pezet, R., Gindro, K., Viret, O., and Spring, J. L. 2004. Glycosylation and oxidative dimerzation of resveratrol are respectively associated to sensitivity and resistance of grapevine cultivars to downy mildew. Physiol. Mol. Plant Pathol. 65:297-303.

36. Pieterse, C. M. J., Van Wees, S. C. M., Hoffland, E., Van Pelt, J. A., and Van Loon, L. C. 1996. Systemic resistance in Arabidopsis induced by biocontrol bacteria is independent of salicylic acid accumulation and pathogenesis-related gene expression. Plant Cell 8:1225-1237.

37. Pineda, A., Zheng, S., Van Loon, J. J. A., Pieterse, C. M. J., and Dicke, M. 2010. Helping plants to deal with insects: the role of beneficial soil-borne microbes. Trends Plant Sci. 15:507-514.

38. Pozo, M. J., Van Der Ent, S., Van Loon, L. C., Pieterse, C. M. J. 2008. Transcription factor MYC2 is involved in priming for enhanced defense during rhizobacteria-induced systemic resistance in Arabidopsis thaliana. New Phytol. 180:511-523.

39. Torres, M. A., Jones, J. D. G., and Dangl, J. L. 2006. Reactive oxygen species signaling in response to pathogens. Plant Physiol. 141:373-378.

40. Trotel-Aziz, P., Aziz, A., Magnin-Robert, M., Ait Barka, E., and Gogniès, S. 2007. Bactéries présentant une activité protectrice de la vigne contre Botrytis cinerea. Patent No. WO2008 009795

41. Trotel-Aziz, P., Couderchet, M., Biagianti, S., and Aziz, A. 2008. Characterization of new bacterial biocontrol agents Acinetobacter, Bacillus, Pantoea and Pseudomonas spp. mediating grapevine resistance against Botrytis cinerea. Environ. Exp. Bot. 64:21-32.

42. Trouvelot, S., Varnier, A. L., Allègre, M., Mercier, L., Baillieul, F., Arnould, C., Gianinazzi-Pearson, V., Klarzynski, O., Joubert, J. M., Pugin, P., and Daire, X. 2008. A $\beta-1,3$ glucan gulfate induces resistance in grapevine against Plasmopara viticola through priming of defense responses, including HR-like cell death. Mol. Plant-Microbe Interact. 21:232-243

43. Vandelle, E., Poinssot, B., Wendehenne, D., Bentéjac, M., and Pugin, A. 2006. Integrated signaling network involving calcium, nitric oxide, and active oxygen species but not mitogen-activated protein kinases in BcPG1-elicited grapevine defenses. Mol. Plant-Microbe Interact. 19:429440.

44. Van Hulten, M., Pelser, M., Van Loon, L. C., Pieterse, C. M., and Ton, J. 2006. Costs and benefits of priming for defense in Arabidopsis. Proc. Natl. Acad. Sci. USA 103:5602-5607.

45. Van Loon, L. C., Bakker, P. A. H. M., Van Der Heijdt, W. H. W., Wendehenne, D., and Pugin, A. 2008. Early responses of tobacco suspension cells to rhizobacterial elicitors of induced systemic resistance. Mol. Plant-Microbe Interact. 21:1609-1621.

46. Van Peer, R., Niemann, G. J., and Schippers, B. 1991. Induced resistance and phytoalexin accumulation in biological control of Fusarium wilt of carnation by Pseudomonas sp. WCS417r. Phytopathology 81: 728-734. 
47. Van Wees, S. C. M., Pieterse, C. M. J., Trijssenaar, A., Van 't Westende, Y. A. M., Hartog, F., and Van Loon, L. C. 1997. Differential induction of systemic resistance in Arabidopsis by biocontrol bacteria. Mol. PlantMicrobe Interact. 10:716-724.

48. Van Wees, S. C. M., Van der Ent, S., and Pieterse, C. M. J. 2008. Plant immune responses triggered by beneficial microbes. Curr. Opin. Plant Biol. 11:443-448.

49. Varnier, A. L., Sanchez, L., Vatsa, P., Boudesocque, L., Garcia-Brugger, A., Rabenoelina, F., Sorokin, A., Renault, J. H., Kauffmann, S., Pugin, A., Clement, C., Baillieul, F., and Dorey, S. 2009. Bacterial rhamnolipids are novel MAMPs conferring resistance to Botrytis cinerea in grapevine. Plant Cell Environ. 32:178-193.

50. Verhagen, B. W. M., Glazebrook, J., Zhu, T., Van Loon, L. C., and Pieterse, C. M. J. 2004. The transcriptome of rhizobacteria-induced systemic resistance in Arabidopsis. Mol. Plant-Microbe Interact. 17:895908.

51. Verhagen, B. W. M., Trotel-Aziz, P., Couderchet, M., Höfte, M., and Aziz, A. 2010. Pseudomonas spp.-induced systemic resistance to Botrytis cinerea is associated with induction and priming of defense responses in grapevine. J. Exp. Bot. 61:249-260. 